\title{
Serine/Threonine-Protein Kinase D3
}

National Cancer Institute

\section{Source}

National Cancer Institute. Serine/Threonine-Protein Kinase D3. NCI Thesaurus. Code C95264.

Serine/threonine-protein kinase D3 (890 aa, 100 kDa) is encoded by the human PRKD3 gene. This protein plays a role in second messenger signal-dependent protein phosphorylation. 